\section{AZ ÁLLAM ÉS A MAGÁNBIZTOSÍTÁSI SZEKTOR SZEREPE A KÖRNYEZETI FELELŐSSÉGI KÁROK RENDEZÉSÉBEN}

Kerekes Sándor (professzor emeritus, Budapesti Corvinus Egyetem), sandor.kerekes@uni-corvinus.hu

Salamon Károly (közgazdász, a Magyar Telekom Felügyelö Bizottságának tagja), miskft@t-online.hu

\section{ÖSSZEFOGLALÓ}

Egyre többen vagyunk a Földön, és egyre nagyobb az az érték is, amit létrehoztunk, és aminek elvesztéséért indokoltan aggódunk. A bioszféra, amelyben élünk, számtalan veszélynek van kitéve. A veszélyt életünket, értékeinket érő fenyegetésként definiálhatjuk. Ez a veszélyeztetés származhat olyan természeti katasztrófákból, mint például azárvizek, a földrengések, a cunamik, a szélviharok vagy földcsuszamlások, a villámcsapások, belvizek vagy éppen az aszály, és ezzel még nem jutottunk a felsorolás végére. A veszély származhat emberi tevékenységtöl is, elég, ha a háztartási vagy üzemi balesetekre, esetleg olyan ipari katasztrófákra gondolunk, mint a zagytározók gátszakadása vagy éppen a reaktorbalesetek. Az egyes károk nagyságrendje a kis károktól a milliárdos nagyságrendü katasztrófakárokig terjedhet. Kérdéses, hogy az elöírások betartása melletti előfordulásuk esetén milyen mértékben vethető fel az állam felelőssége és szerepe a károk helyreállításában, illetve a jövőbeni esetek elkerüléséhez szükséges intézkedések meghozatalában. A környezeti károk területén bevezetendő szigorú intézkedések az egyes nemzeti iparágakra lehetnek akár hátrányosak is, és rövid távon csökkenthetik a terület eredményességét, illetve tőkevonzó képességét. Az állam további kármegelöző és így költségnövelő intézkedésekre késztetheti a vállalkozásokat, ami rövid távú gazdasági hátrányt jelent, de a másik oldalon a kikényszerített magatartás a gazdasági hátrányt meghaladó környezeti előnyt és élhetőbb világot eredményezhet. A cikk arra keresi a választ, hogyan lehet ebbe a folyamatba a magánbiztosítókat bevonni, és az átmeneti időszakban mi azállam szerepe a környezettudatos működés erősítésében.

\section{SUMMARY}

We see a continuous growth in our world not only in a sense of an increasing number of people living in our planet, but also in terms of value created by us via our activities. We are facing to various dangers including floods, earthquakes, and other natural catastrophise, which provide threat to our everyday life. We may not disregard the impact of the manmade disasters as well, referring not only to the domestic accidents, but also to the big industrial ones. The value of the claims occurred may extend from the small household claims up to the ones reaching the magnitude of billion USD. Let us just think of the accidents of the atomic reactors, the red mud catastrophise, happened during the last couple of years, or of the erratic usage of hazardous waste materials. The question is, keeping the rules and regulations which extent raises the responsibility of the State in restoring the claims, and introducing preventive measures. The introduction of preventive measures may result additional costs or even in short term a reduced competitiveness, but in long term they contribute to a cleaner environment and liveable world. The article is looking for an answer, how the insurers can be involved in this process, and what is the role of the state during the transitionary period.

Kulcsszavak: környezeti kockázatok, kötelező felelősségbiztosítás, felelősségmegosztás Key words: environmental risks, compulsory liability insurance, division of liability

JEL: G22, K32

DOI: $10.18530 / B K .2019 .3 .34$

http://dx.doi.org/10.18530/BK.2019.3.34

\section{A környezeti kockázatok társadalmi-gazdasági jellegzetességei}

\section{Viszonyunk a kockázatokhoz}

A környezetvédelemben a természeti és ipari veszélyeztetéseket a kockázatok között tartják számon. Kockázatnak egy életünket, értékeinket érő fenyegetés bekövetkezési valószínűségének és a bekövetkezett esemény által okozott kárnak a szorzatát tekintik. Mióta ismerjük ezeket a jelenségeket, arra törekszünk, hogy csökkentsük a kockázatokat. Ennek egyik lehetséges módja, hogy próbáljuk csökkenteni a bekövetkezési valószínűségeket. A földrengések gyakoriságát ugyan nem tudjuk befolyásolni, de földrengésbiztos építési módszerekkel a bekövetkező földrengés miatti károkat igen. Napjainkban viszonylag sikeresen védekeznek - legalábbis a gazdag országok - az árvíz pusztítása ellen. A fejlett katasztrófavédelemmel rendelkező OECD országokban sem az árvizek, sem a tűzvész nem követel túl nagy emberáldozatot. Amikor emberéletről van szó, egyetlen felesleges emberáldozat is elviselhetetlenül nagy. A kockázatok általában tömegjelenségek, és mint ilyenek, a valószínűségszámítás szabályai szerint kiszámíthatók. Aki autóba ül, és megtesz bizonyos távolságot, az vállalja, hogy menet közben balesetet szenvedhet - ami a legrosszabb esetben akár az életébe is kerülhet, vagy tartós egészségkárosodás következhet belöle. Bizonyos kockázatokat kénytelenek vagyunk vállalni, mert a védekezés túl sokba kerülne, vagy mert éppen örömünket leljük a kockázatos tevékenységben. Gondoljunk például az autóversenyzőkre vagy a hegymászókra, hogy csak a legkézenfekvőbbeket említsük. Mindkét jelenségre létezik statisztika, ami azt mutatja, hogy ezek a tevékenységek kockázatosak, de vannak veszélyes foglalkozások is, mint például a rendőr, a berepülőpilóta, a tűzoltó vagy a hegyimentő 


\section{A kár okozta társadalmi feszültség természete}

A kockázatokkal együtt lehet élni, ha önként vállaljuk azokat, vagy ha elkerülhetetlenek. Ki kell mennünk az utcára, és a fejünkre eshet egy cserép, amit a korábbi vihar meglazított. Annak a valószínűsége, hogy a cserép a fejünkre esik, elég kicsi ahhoz, hogy egy egészséges ember ne rettegjen a félelemtől, amikor az utcára lép. Nem akarunk együtt élni olyan kockázatokkal, amelyek elkerülhetők lennének, és még kevésbé fogadjuk el azokat a kockázatokat, amelyeket mások haszonszerzése miatt nekünk kell elviselnünk. A jogi szakirodalom ezt úgy fogalmazza meg: „társadalmi feszültség” keletkezik, amit valamilyen beavatkozással meg kellene szüntetni. Bárdos ezzel kapcsolatban lényegre törőn fogalmaz: „Önmagában az, hogy elvben van olyan, akit a másnak okozott kárért akár saját magatartása, akár érdekeltsége okán felelőssé lehet tenni, még egyáltalában nem garantálja, hogy a kárkompenzáció, tehát a kár miatt elóállott társadalmi feszültség megszüntetése mint cél, a konkrét esetben ténylegesen megvalósítható. Ennek két fö oka képzelhető el: vagy az, hogy nem lehet találni olyan személyt, akit az előzők szerint a bekövetkezett kárért felelőssé lehetne tenni, vagy pedig, mert noha a felelős megvan, az egyszerűen helyzeténél fogva nem képes a kár kompenzálására." (Bárdos, 2004, p.12.) A környezetvédelemben előforduló katasztrófaesetek zöme abba a kategóriába tartozik, amelyeknél a károkozó ugyan ismert, de helyzeténél fogva nem képes a kár kompenzálására. Elég példaként a Union Carbide-ot említeni, de közelebb is találunk olyan káreseteket, mint például a MAL Zrt. vörösiszapkára, amelynél a károkozó fizetésképtelenné vált, felszámolási eljárás alatt van, és a kártérítést nem tudta kifizetni. A jog erre vonatkozóan is eligazítással szolgál, amikor arról beszél, hogy ki kell építeni a kárenyhítésre egy második lépcsőt. E második lépcső a veszélyközösségek szervezése. A veszélyközösségek többnyire biztosítási alapon jönnek létre, ezen belül is önkéntes vagy kötelező biztosítás formájában. Az olyan esetekben, amikor a kár dimenziói, katasztrófajellege folytán még ez a védelem sem elegendő, szerephez jut az önkormányzat vagy az állam, amely költségvetésén keresztül tulajdonképpen maga is veszélyközösség, az adózó állampolgárok veszélyközössége. Bizonyos esetekben pedig a veszélyközösség átlépheti az országhatárokat, és nemzetközivé válhat, jórészt szolidaritási, emberiességi alapon." (Bárdos, 2004, p. 3.)

A probléma elvileg megoldható volna, a jog világosan fogalmaz, azonban a gyakorlat mást mutat. A garéi hulladékot nagyrészt az állam költségén takarították el, Kolontárt állami költségen építették újjá, és nem a Union Carbide (Trotter, Day, \& Love, 1989) gondoskodik a nyomorékká vált indiai emberekről sem, az atomerőmű sem kártalanította a csernobili reaktorbaleset károsultjait. Vannak persze pozitív példák is, mint például az Exxon esete, amelyik az USA-ban kompenzálta a károsultakat. De vajon kompenzálta volna-e őket, ha az esemény nem Amerikában történik?

\section{A jog és a gazdaság eltérő kockázatértelmezése}

Az emberek bizalma nem véletlenül rendült meg a szabályozó hatóságokban. Általában nemigen kapunk választ még az olyan egyszerű kérdésekre sem, mint például, hogy melyik része és mennyire szennyezett a környezetünknek, és arra meg végleg nem, hogy milyenek lehetnek a környezetünk egészségügyi kockázatai. (Barnes, 2002, p. 21.)

Sajnos a kockázati és a jogi szakirodalom nem azonosan használja a kockázat fogalmát. A jog szerint: „A kockázat csak azt jelenti, hogy egy esemény nem biztos.” (Szalai, 2017) Persze ennek a felfogásnak is megvan a maga logikája, de nem könnyíti meg a helyzetünket, ha már a fogalmakat illetően sem tudunk egyetértésre jutni. A jogi kockázat: ,amikor a közvetlen károkozó fizetési kötelezettsége nem függ attól, hogy bekövetkezik-e a kár, attól függetlenül fizetnie kell. Például biztosítási díjat kell fizetnie, vagy valamilyen büntetést rónak rá attól függetlenül, hogy bekövetkezett-e amiatt kár." (Szalai, 2017) A kockázat közgazdasági, biztosításszakmai megközelítése szerint kockázat alatt azt értjük, hogy történik valamilyen esemény, vagy csinálunk valamit, annak tudatában, hogy lehetséges annak negatív kimenetele is. Saját kockázat esetén vállaljuk is annak a tevékenységnek a következményeiért a felelősséget. A biztosítás olyan szolgáltatás, ahol az ügyfél a vásárlás pillanatában nem „kézzel fogható” terméket kap, hanem egy ígéretet arra, hogy egy esetleges káreset bekövetkezésekor a biztosító helytáll helyette. Az ügyfél a köztes időszak „nyugodt alvását” vásárolja meg.

Követelhető-e kártérítés egy szabályozó, ellenőrző hatóságtól, ha az általa ellenőrzött iparág valamely szereplője okoz kárt?

A jogi szövegek értelmezése a közgazdász számára nem egyszerű feladat, de talán megéri az erőfeszítést. A „másért viselt felelősségen” Szalai Ákos a következőket érti: „(i) van ugyan egy jól azonositható közvetlen károkozó (K), a jogrendszer mégis megengedi, vagyéppen kifejezetten meg is követeli, hogy a károsult (Â) ne tőle, hanem egy kijelölt személytől (M-től) kérjen kártérítést, (ii) a közvetlen károkozó (K) és a másik személy $(\mathrm{M})$ között ex ante olyan kapcsolat áll fenn, amelyben a felek közötti előzetes kommunikáció esélye nem kizárt." (Szalai Ákos, 2016 p. 3.)

Természetesen nem bajlódnánk a jogértelmezéssel, ha az nem éppen a felelösségbiztosítás logikájának elvi alapjait jelentené. A Biztosító a potenciális károkozóval folytatott „előzetes kommunikáció” alapján szerződést köt, és fedezetet nyújt a vétkes vagy vétlen károkozásra is. A „másért viselt felelősség” körébe tartoznak a témánk, a kockázati felelősségbiztosítás szempontjából legfontosabb kérdések. Így például az anyavállalat felelőssége a leányvállalata által okozott károkért, vagy olyan kérdések, mint például „követelhető-e kártérítés egy szabályozó, ellenőrző hatóságtól, helytállásra kötelezhető-e az, ha az általa ellenőrzött iparág valamely szereplője okoz kárt (például egy bankfelügyelet egy banki termék általa okozott kárért, vagy egy iparbiztonsági hatóság egy ipari katasztrófáért?" (Szalai, 2016)

A jog a „másért viselt felelősség” körében tárgyalja a felelősségbiztosítás esetét is. Ezt annyiban tekinti speciálisnak, hogy a biztosító, nem törvényi elöírásra kényszerből, hanem 
önként vállalja át a közvetlen károkozótól a kártérítés megfizetését. (Szalai, 2016). Tény, hogy a vagyonbiztosításokkal az ügyfél a saját vagyontárgyai megőrzéséről és működőképességéről igyekszik gondoskodni, míg a felelösségbiztosításokkal a harmadik féllel szembeni esetleges kötelezettségeinek fedezetét igyekszik megteremteni.

A „másért viselt felelősség” elvének a kimondása mellett általában két érvet hoz fel a jogi irodalom. Az egyik az úgynevezett reparáció kérdése, a másik a kármegosztás érve. „A reparáció érve szerint, ha a közvetett károkozótól (is) kérhető a kár, akkor a károsult számára lehetővé tesszük, hogy egy „mélyebb zsebet” érjen el.” Ez a valóságban csak akkor jelent nagyobb biztonságot a reparációt illetően, ha a közvetlen és közvetett károkozók egyetemlegesen felelősek. (Szalai, 2016). A felelősségbiztosításoknál erősebb az az érzés, hogy a véletlen esemény velünk nem fog előfordulni, és kevésbé vagyunk igényesek a szolgáltatás minőségét illetően, hiszen úgysem mi leszünk a haszonélvezői. Mindez, ha nincs központi akarat, illetve a kockázatok helyes felmérése könnyen nem megfelelő, nem kockázatarányos biztosítást eredményezhet.

\section{A kármegosztás és a „szennyező fizet” elv ellentmondása}

A kármegosztás elve a közvetlen károkozó kockázatát hivatott csökkenteni. Ezzel például elkerülhető, hogy egy káresemény következtében azonnal csődbe menjen egy vállalkozás. Természetesen a közvetlen károkozó csak akkor mentesül a kockázat terhei alól, ha nincs utólagos kártérítési kötelezettsége. „A joggazdaságtani irodalom ugyan kidolgozza a hatékonyságelvü jobb kockázatviselö tesztjét, de e mögött is alapvetően prevenciós (és részben hatékony elosztási, igazságossági) elvek húzódnak meg." (Szalai, 2016)

A környezetvédelemben a számos alapelv közül, az előzőeket értelmezve, kettővel is gondjaink akadnak. Az egyik a „szennyező fizet elv”, ami a felelősségbiztosítással sérülni látszik. Nem a szennyező fizet közvetlenül, hanem helyette a „másért viselt felelősség” alapján valaki más, például a biztosító. A másik a „,megelőzés elve”. A jogban és a gyakorlatban „,a prevenció nem azt szolgálja, hogy a kárveszélyt kiküszöböljük, hanem azt, hogy csökkentsük... az esetek többségében nem is értelmes cél a kárveszély teljes kiküszöbölése (csak optimális mértéküre csökkentése)." (Szalai 2016). A biztosításban a felelősségi szabályokat két nagy kategóriába soroljuk. A veszélyes üzemi tevékenységekhez nem kötelezően kötődő objektív felelősségre, illetve a felróhatóság-alapú felelősségre. Objektív-tárgyi felelősségként fogunk hivatkozni a szakirodalomban strict liabilityként ismert formára, vagyis amikor a felelősség megállapításakor nem vizsgálják a károkozó elővigyázatosságát, nem mentheti ki magát a kártérítés fizetése alól - mindenképpen meg kell fizetnie a kártérítést. Az új Ptk. a kontraktuális kártéritési rendszert objektív jogalapra helyezi, és eltérő kimentési rendszert határoz meg: mentesül a felelősség alól, ha bizonyítja, hogy a szerződésszegés az ellenőrzési körén kívül következett be, a körülményt a szerződéskötéskor nem láthatta, valamint nem volt elvárható a kár elhárítása.

A másik a vétkességi és a felróhatósági felelősség. Előbbi alatt minden olyan rendszert értünk, amely ismeri az elvárhatóság fogalmát: mentesül a felelősség alól a károkozó, ha elvárhatóan jár el. A felróhatóság ezzel szemben konkrétabb: azt jelenti, hogy az elvárhatóság szintje a magyar jogban ismert felróhatósághoz kapcsolódik, vagyis ez az adott esetben általában elvárható magatartást jelenti, és nem annál magasabb szintet.

A jog elismeri és „megjutalmazza” a prevenciót, de csak a megfigyelhető elővigyázatosságot ismeri el a bírósági gyakorlatban, és ez nem ugyanaz, mint amit a környezetvédelmi gyakorlatban a „megelőzés” elve jelent. A jogi felfogás szerint „a prevenciós hatások elemzésekor a fö kérdés, hogy mit tesz valaki a káresemény esélyének csökkentése érdekében. Az ezzel foglalkozó irodalom az ilyen „esélybefolyásoló” lépések három formáját különíti el: (i) a megfigyelhető és a (ii) nem megfigyelhető elővigyázatosságot, valamint (iii) az „aktivitást”. Az „adott elővigyázatossági szint mellett is változhat a baleset esélye, attól függően, hogy hányszor, milyen mennyiségben végezzük az adott kárveszélyt hordozó tevékenységet: Ha nagyobb az aktivitás, nagyobb a kárveszély.' (Szalai, 2016).

\section{A felelősségbiztosítás szerepe a kockázatok kezelésében}

\section{A felelősségbiztosítási kultúra létrejöttének buktatói}

A biztosítási kultúrát, mint általában minden kultúrát, hosszú évek tapasztalatai alakítják. A felelősségbiztosítások a (katasztrófa) károk esetén a természeti károkon túl a nem szándékos emberi mulasztásból okozott károkra is fedezetet nyújtanak. A megfelelő felelősségbiztosítás hiányában az évekig elhúzódó pereskedés rontja a biztosításba vetett bizalmat, miután a vagyonbiztosítások bizonyos emberi tevékenység miatti károkra nem nyújtanak fedezetet (lásd például a köröndi tüzkár esetét). A súlyosabb eseteknél előforduló, emberéletben okozott, illetve személyi sérüléses károknál a biztosítási helyzet még összetettebb. A felelösségbiztosítás tipikusan hosszú távú (long tail) üzlet, ahol a káresemények bejelentése és az ügyintézés lefutása a személyi sérülések következtében sokkal hosszabb időt vesz igénybe, mint a vagyonbiztosítások esetén. Mivel a károk felismerése, bejelentése a termék használata, üzemeltetése után akár évekkel később is történhet, sokkal nagyobb a bizonytalanság a biztosítási termékek árazásában, illetve a helyes kárrendezési gyakorlat kialakításában. Nem véletlen, hogy a biztosítási termékek közül különösen árérzékeny a gépjárművek kötelező felelősségbiztosítási piaca. Általában a biztosítások, így a felelősségbiztosítások létezési alapját az ügyfelek kockázatkerülő magatartása adja. Az egyszeri nagy veszteség egy káresemény kapcsán fájdalmasabban érintené őket, mint a relatíve kis összegü biztosítási díj folyamatos fizetése. A racionális ügyfél kockázatkerülő, a nagy veszteséget kívánja elkerülni, ezért a biztosítás nyújtotta védelem megszerzése mellett dönt. (Pandurics, II. évf. 3. szám). Sokan úgy gondolják, hogy az egyének és vállalatok döntései azon a feltevésen alapulnak, hogy az emberek - vevők, alkalmazottak, menedzserek - racionális döntéseket hoznak, és a piac „láthatatlan keze” alkalmas arra, hogy megbízhatóan korrigálja a kilengéseket. (Ariely, 2009 July-August) A gyakorlat azt mutatja, hogy az események és intézkedések inkább befolyásolják az embereket a biztosításvásárlási döntéseikben, mint a racionalitás. Legfeljebb utólag gondolják, hogy logikus lett volna az adott kockázatra fedezetet vásárolni. A biztosítási szakmában uralkodó vélemény szerint nem véletlen: a káreset és a jó kárrendezés a legjobb reklám. 


\section{Veszélyes üzem esetén alkalmazható felelősségi szabályok}

A veszélyes üzemi felelősség azt jelenti, hogy jogi személyként viseli ex post az abból a tevékenységéből fakadó kárt (és ex ante annak a kockázatát) is, ami neki nem felróható. Ha az üzemben tartó és a közvetlen károkozó nem ugyanaz a jogi személy, akkor a felróhatóság nélkül is bekövetkező károkat (illetve azok kockázatát), illetve a közvetlen károkozó fizetésképtelensége miatt meg nem térülő kárt (illetve annak kockázatát) is az üzemben tartó viseli. Veszélyes üzemi felelősség esetén az üzemben tartó csak akkor mentesülhet a felelősség alól, ha a kárt a fokozott veszéllyel járó tevékenység körén kívül eső, elháríthatatlan ok okozta. (Szalai, Veszélyes üzemi felelősség - Joggazdaságtani hatások, 2015. II. évf.) Az elháríthatatlan ok az, amely a konkrét ügyben, a technika adott fejlettségi szintjén, emberi erőfeszítéssel általában (objektíve) nem hárítható el. (Ádám, 2015) Az egyik legizgalmasabb kérdés, hogy a lehetetlenülés magában foglalja a „gazdasági lehetetlenülés” kategóriáját - a társadalom teherbíró képességének vizsgálatát. (Közlekedési vállalat felelőssége, amennyiben a járaton bomba robban.) A gazdasági elháríthatatlanság figyelembevétele vagy figyelmen kívül hagyása az, ami meghatározza a veszélyes üzemi felelősség elméleti besorolását. Különböztessük meg itt a felelősség két fö formáját, a vétkességi (negligence) és az objektív-tárgyi (strict liability) felelősséget! A kettő között a fö eltérés az, hogy az elővigyázatossággal kapcsolatos elvárások teljesítése mentesíti-e a jogellenesen kárt okozót a felelősség alól. Amennyiben tehát a magyar veszélyes üzemi felelősségnek része egy gazdasági elháríthatatlansági teszt, akkor végső soron a vétkességi felelősségen belül maradunk, hiszen azt is vizsgáljuk, hogy - a teherbíró képességre is figyelemmel - elvárható lett volna-e a károkozótól a kár elhárítása.

\section{A kártérítési rendszer keretében alkalmazott ösztönzők}

„Közgazdasági értelemben minden kártérítési rendszer biztosítás: a károsult kárait vagy legalábbis azok egy részét valaki - itt: a károkozó, a felelős, a helytáló - megfizeti számára. Éppen ezért érdemes a károsult ösztönzőit a biztosítás irodalmából kölcsönvett fogalommal, az ex ante morális kockázattal leírni: akinek nem kell a teljes kárát viselni (esetleg semmiféle kárt nem kell viselnie), az veszélyesebb tevékenységekbe kezd, nagyobbra növeli ezen aktivitását, kevésbé lesz elővigyázatos, mint ahogyan akkor tenne, ha ilyen biztosítása nem lenne." (Szalai, 2016)

A biztosításban a kártérítési rendszerek kétféle ösztönzőt hordozhatnak magukban: a költségalapú és az elvárásalapú ösztönzőt. Az elvárásalapú ösztönzés hatása attól függ, hogy milyen elvárásokat fogalmazunk meg. Ha ezek szintje „téves”, akkor ehhez a téves szinthez fognak alkalmazkodni a potenciális károkozók. Költségalapú ösztönzés esetén a fö veszély a kártérítés „téves” meghatározása. A két felelősségi forma közötti választásnál eldöntendő kérdés tehát az is, hogy melyik tévedés esélye, súlya nagyobb.

A veszélyes üzemi felelősség és a felróhatóságon alapuló felelösség eltérő prevenciós ösztönzőket hordoz. A veszélyes üzem esetén alkalmazható objektív felelösség, pontosabban annak kimentési szabálya úgynevezett költségalapú, szemben a felróhatóságon alapuló felelősséggel, ami elvárásalapú ösztönzőt teremt. A kérdés az, hogy miben tér el a veszélyes üzemi felelősség ösztönzési hatása a felróhatóságon alapuló felelősségétől, ugyanis mind a két felelősségi formának van preventív, az elővigyázatosságot ösztönző hatása. Mindkettő hat az elővigyázatosságra, csak más módon.

A vétkességi felelősség mind a kettőt, az objektív-tárgyi felelősség csak a költségalapú ösztönzőt tartalmazza. Utóbbinál a károkozót az elővigyázatossági lépések megtételére és ezzel azok költségeinek felvállalására az motiválja, hogy kisebb valószínűséggel okozzon balesetet, hiszen baleset esetén szinte mindig kártérítést kell fizetnie. Ugyanazt az elővigyázatossági lépést és emiatt ugyanazt a többletköltséget inkább felvállalja valaki, ha magasabb kárra, pontosabban magasabb kártérítésként megítélt összegre számít. Ez a költségalapú ösztönző: a magasabb kártérítési összeg nagyobb elővigyázatosságra serkent.

A biztosításban a kártérítési rendszerek kétféle ösztönzőt hordozhatnak magukban: a költségalapú és az elvárásalapú ösztönzőt.

A vétkességi felelősségnél elvileg megjelenik az elvárásalapú ösztönző is. Vétkességi felelősség esetén a kártérítési felelősség megszűnik, vagyis a kártérítés összege nullára csökken, ha az elvárható szintet eléri az elővigyázatosság. A potenciális károkozó két alternatíva közül választhat: (1) vagy teljesíti az elvárást, és akkor nem fizet kártérítést, (2) vagy - ha az elvárást túl magasnak találja - figyelmen kívül hagyja azt, és vállalja, hogy kár esetén megfizeti a kártérítést. Látszik ebből, hogy az elvárás emelése egy ideig (amíg annak szintje „túl magas” nem lesz) emeli az elővigyázatosság szintjét: a károkozó igyekszik teljesíteni a magasabb szintet is, hogy elkerülje a kártéritési kötelezettség teljesítését. A két felelősségi forma közötti választás egyik legfontosabb szempontja az kellene, hogy legyen, hogy melyik prevenciós rendszer hoz nagyobb elővigyázatosságot. (Szalai, 2015)

\section{A pénzügyi biztosítékadás korlátai}

A környezethasználó külön kormányrendeletben meghatározott tevékenységéhez környezetvédelmi biztosíték adására köteles, továbbá a tevékenységével okozható, előre nem látható környezetkárosodások felszámolása finanszírozásának biztosítása érdekében - külön jogszabályban meghatározott feltételek esetén - környezetvédelmi biztosítás kötésére kötelezhető. (1995. évi LIII. törvény a környezetvédelem általános szabályairól)

A fentebb leírt mindkét ösztönzőrendszer befolyásolja a pénzügyi biztosíték és ezáltal az alkalmazható biztosítás jellemzőit. A biztosítási díj a biztosítási összegtől (a maximális kártérítés mértékétől), továbbá az adott tevékenységből származó bekövetkezés valószínűségétől, illetve az alkalmazott kizárásoktól függ. Az, hogy milyen prevenciós intézkedésekre ösztönözzük a vállalkozásokat, és ezáltal nagyobb elővigyázatosságot várunk-e bizonyos tevékenységektől, az befolyásolhatja az adott tevékenység költségstruktúráját, és ezáltal nyereségtermelő képességét, ez pedig befolyásolhatja a tőkevonzó képességüket. 
Ezen intézkedések meghozatala nyilvánvalóan befolyásolhatja a biztosítási díj mértékét, de sok esetben azt szolgálja, hogy elérjék a biztosíthatóság szintjét.

Amennyiben az elvárt elővigyázatosság meghaladja (de nem „túlzottan”) azt, amit tiszta költségalapú ösztönző esetén a potenciális károkozó választana, akkor az elvárásalapú ösztönző magasabb elővigyázatossághoz vezet, de ez nem befolyásolja az esetleges pénzügyi biztosíték szintjét.

A felelősségbiztosítások létrejöttének akadályai

\section{Az állami szerepvállalás jelentősége}

Az egyes meghatározott tevékenységekhez kötött engedélyek kiadása az államnak alárendelt felügyelő hatóságok feladata. A hatóságok határozzák meg, hogy bizonyos tevékenységek végzéséhez milyen engedélyek szükségesek. Amennyiben a károkozó rendelkezik az elöírt engedéllyel, az elöírásokat betartva végezte a tevékenységét, és a káresemény mégis bekövetkezett, felvetődik a kérdés a felelösségnek a károkozó és hatóság közötti megosztását illetően. Ha a mindenkori szabályozó hatóság meghatározta az elvárható gondosság és a pénzügyi biztosíték szintjét, majd a káresemény bekövetkezésekor a biztosítási összeg alacsonynak bizonyul, a károsult a kárigényét a kármegosztás alapján nemcsak a károkozóval szemben, hanem akár az állammal szemben is érvényesítheti.

\section{Komoly érvek szólnak a károkozó és az állam}

\section{közti kármegosztás mellett.}

A károkozást eredményező tevékenység közvetlen haszonélvezője a tevékenységet folytató gazdasági szereplő. Miután a vállalkozás a bevételei után különböző jogcímeken, például adókon keresztül az állam is részesül, így komoly érvek szólnak a károkozó és az állam közti kármegosztás mellett. (Csapó, 2015)

A tevékenység folyamatos monitorozása és olyan szabályozó rendszer kialakítása, olyan prevenciós intézkedések meghozatala, amelyek biztosítják az esetleges károk bekövetkezése esetén a megfelelő kártérítés lehetőségét is, a felügyelő hatóság feladata. Amennyiben a károkozó vagy biztosítója nem tud helytállni a kártérítés kötelezettségeinek, a vétlen harmadik felet akkor is kártalanítani kell, és ennek jogi feltételeit a hatóságoknak kell megteremteniük (lásd MÁV Biztosító Egyesület csődje után a kártalanítási alap (KALAP) létrehozása).

A felügyelő hatóság bizonyos tevékenységek műveléséhez megfelelő mértékű pénzügyi biztosíték létrehozását, esetleg a kötelező felelősségbiztosítás megkötését írhatja elő. Léteznek olyan területek, ahol azállam kötelezően előírja a felelösségbiztosítás meglétét, de a piacra bízza a kondíciók - biztosítási összeg, önrész, limitek - kialakítását. Példaként említhetjük a felszámolók, biztosítási alkuszok, hitelközvetítők stb. kötelező felelősségbiztosítását, ahol az elvárt fedezetet is meghatározza, csak az ár kialakítását bízza az érdekelt felekre.
Az állam kiemelt feladata a gazdasági növekedés ösztönzése, az ország tőkevonzó képességének a javítása, a befektetések ösztönzése is. Feladata a fenntartható fejlődés biztosítása is, ami a gazdaság, a társadalom és a környezet szoros együttműködésére épül azért, hogy ne éljük fel a későbbi létezés tartalékait, lehetőségeit. Olyan előírások, amelyek további terhet rónak a vállalkozásokra - mint például az egyes területeken kötelező felelősségbiztosítások bevezetése, kártalanítási alapokhoz való hozzájárulás elöírása -, rövid távon hátrányos lehet a nemzeti iparágak számára. Csökkentheti a versenyképességüket, mert további védelmi intézkedések bevezetését várja el tőlük, ami addicionális költségekkel jár. Ezek a pillanatnyi gazdasági hátrányok környezetvédelmi előnyökkel járnak, és hosszabb távon a befektetői bizalom erősítéséhez járulnak hozzá.

Nem elhanyagolható az állam szerepe, felelősségvállalása, aktív részvétele a kárrendezési folyamatban olyan esetekben, amikor a károkozás - jellemzően környezetszennyezés országhatáron túl nyúló tevékenységből származik.

\section{A környezeti kockázatok biztosíthatósága}

Az ipari termelés következtében a természeti erőforrások veszélyeztetése és a veszély bekövetkezésekor keletkezett károk externáliának számítanak, és a „külső” (harmadik) fél, általában a társadalom egésze által elszenvedett veszteségnek tekinthetők. A cél ezen károk felszámolása és a felszámolás költségeinek az iparágon belül tartása, amit különböző jogi eszközökkel lehet elérni. A felügyelő hatóság előírásai és ajánlásai útján „ex ante” befolyásolja a piaci szereplők viselkedését, másrészt a felelősségi károk rendezésekor és esetleg a rendezés bíróság általi kikényszerítésekor ex post próbálja a problémát kezelni.

A kötelező felelősségbiztosítás melletti fö érv, hogy a kár nagysága gyakran meghaladja a károkozó egyéni vagyonát, emiatt az áldozatok alulkompenzálásának a veszélye merül fel. Az ügyvédek ezért a kötelező biztosítás előmozdítása melletti érvként használják az áldozat hatékony ellentételezésének biztosíthatóságát. Ez a (disztribúciós) érv nyilvánvalóan szerepet játszhat bizonyos kockázatok biztosításában is. Vegyük például a környezetszennyezés példáját: ha egy károsult esetében bizonyított a kár, például az egészségkárosodás következményei révén, de a szennyezésnek nincs gazdája, a költségeket a társadalom kénytelen viselni.

Lehetséges azonban gazdasági érv arra is, hogy a fizetésképtelenség a biztosítással orvosolható lenne, de csak elvileg. A potenciális károkozó a lehetséges kárnál általában kisebb kárra köt biztosítást. Ha a várt kár nagymértékben meghaladhatja a károkozó vagyonát, akkor a károkozót ez arra ösztönzi, hogy csak a saját vagyona fedezetére vásároljon biztosítást. Egy biztosítási szerződés keretében ugyanis legfeljebb a saját vagyonát veszítheti el. (Faure, 2006)

A környezeti felelősségbiztosítási kockázatok kezelése szoros kapcsolatban van a mindenkori jogi és szabályozó környezettel, ami a biztosítók számára az alaptevékenység által vállalt kockázaton túl további, jogi kockázatot is jelent. A biztosítók által vállalt 
kockázatot tovább növeli az információs aszimmetria a biztosító és a biztosított vagy annak képviselője között. A technológiák, felhasznált anyagok folyamatos változása további, úgynevezett fejlődési kockázatot rejt magában. A környezetszennyezési károk bekövetkezése (szennyezés), felismerése és a károk helyreállítása időben nehezen behatárolható. Az ilyen, hosszabb időt is igénybe vevő (long tail) üzlet árazása különösen nehézkes. Nagyrészt emiatt a biztosítók ezen a területen erősebben kockázatkerülők. Mindez megköveteli a modern biztosítási eszközök alkalmazását, ami a biztosító és a biztosított között sokkal szorosabb és hosszabb távú együttműködést igényel. Az együttmüködés kiterjed a rendszer kialakítására, a kockázatmenedzselési stratégiára, valamint annak folyamatos ellenőrzésére, monitorozására. Sajnálatos, hogy a megfelelő kockázatkezelési rendszer kialakítása és annak a biztosítók szakértői általi ellenőrzése és jóváhagyása után sokan úgy érzik, hogy nincs is a szükség a biztosításra. A megkövetelt intézkedések és azok jóváhagyása a biztosító által feltétele a biztosíthatóságnak, de nem zárják ki a jövőbeni balesetek bekövetkezésének a lehetőségét. A társaságok nem megfelelő viselkedése azt mutatja, hogy a környezeti felelősségbiztosítás megkötésére vonatkozó törvényi előírás hiányában a vállalkozások megelégszenek az elvárt megelőző intézkedések megtételével, de a biztosítás megkötését már felesleges teherként élik meg. (Monti, 2002)

\section{A felelösségi károk biztosításának tapasztalatai az Európai Unióban}

A felelősségbiztosítási piac fejlődése jól mutatta, hogy szükséges olyan európai uniós felelősségi irányelv bevezetése, amely igyekszik harmonizálni az egyes országokon belüli jogalkotást, illetve útmutatást ad a határokon átnyúló felelősségi károk rendezésére. A 2000. január végén bekövetkezett tiszai cianidszennyezés is felgyorsította a környezeti felelőséggel kapcsolatos irányelvek elfogadását, és a MAL Zrt. vörösiszap-katasztrófájának a megítélésére is erős hatással bírtak az abban lefektetett irányelvek.

Az Európai Unió jogrendszere szerint a környezet védelme a közösségi politikák egyike. A Bizottságnak a környezetben okozott károkért való felelősség szabályozására irányuló javaslata először 1993-ban az ún. Zöld könyv formájában került publikálásra, mely erősen a károsultak szempontjából szigorú objektív felelősség mellett érvelt. A 2000ben elfogadott Fehér könyv már egy vegyes rendszer kialakítását támogatta, amely szerint a veszélyes tevékenységek esetén a szigorú és objektív felelősség elve is alkalmazható, miközben a biodiverzitásban bekövetkező károk esetén a vétkességalapú felelősség mellett tette le a voksát. A 2004-ben elfogadott Európai Uniós Irányelv a Környezeti Felelősségről meghatároz minimum sztenderdet a megelőzéssel és a környezeti károk helyreállításával kapcsolatosan, és kimondja a károkozó fizet elvét. (Martin-Ortega-Brouwer-Aiking, 2011) Az irányelv elöremutató a kár és a környezeti kár meghatározása tekintetében. A kár valamely természeti erőforrásban közvetlenül vagy közvetve bekövetkező, mérhető kedvezőtlen változás, illetve valamely természeti erőforrás által nyújtott szolgáltatás közvetlen vagy közvetett mérhető romlása. Előrelépés, hogy nem csupán az erőforrás sérülése, hanem bármely mérhető romlás kárként érvényesíthető. Nemcsak az erőforrás, hanem az általa nyújtott szolgáltatás - pl. a köz érdekében betöltött funkció - sérelme esetén is kárról beszélhetünk. (Environmental Liability Directive, 2004) Felállít egy listát azokról a környezetre veszélyes tevékenységekről, ahol az objektív felelösséget kell alkalmazni. Ezeket az elveket kell átültetni az egyes tagállamok joggyakorlatába, illetve átültetni a biztosítótársaságok kárrendezési gyakorlatába. Az utóbbi években egyre erősebben merül fel az úgynevezett NATECH (Natural Hazard Triggering a Technological Disaster) kockázatok kezelése. A kolontári vörösiszap-katasztrófánál a felelősséget csökkentő érvként merült fel a szokatlanul heves esőzés a katasztrófát megelőző időben. A legszélesebb körben érthetően a földrengések következtében fellépő technológiai katasztrófákkal, mint például a fukushimai atomkatasztrófával foglalkozik a szakirodalom. (Cruz-Steinberg-Vetere Arellano-Nordvik-Pisano, 2004) Megjelennek a szakirodalomban a klímakatasztrófák biztosításának a kérdései is. (Telesetsky, 2009)

\section{Az Európai Unió jogrendszere szerint a környezet}

\section{védelme a közösségi politikák egyike.}

A környezeti károk felszámolásához szükséges pénzügyi fedezet előteremtéséhez komoly pénzügyi biztosítékokra lenne szükség. A Bizottság még vizsgálja egy kötelező biztosítékrendszer kialakításának szükségességét. Jelenleg nyolc olyan európai ország van, ahol jóváhagyták a kötelező pénzügyi biztosíték rendszerének bevezetését az Irányelvben meghatározott tevékenységek esetén, amely a "szennyező fizet" elvvel szemben más megoldást, például a biztosítók helytállását is lehetővé teszi. A folyamatos díjfizetési kötelezettség és annak megfelelő mértéke várhatóan a kockázat csökkentésére ösztönzi az üzemben tartókat. (Peleckis-Peleckiene-Simelyte, 2015)

A Public Private Partnership egyik gyakori, de kevéssé vizsgált esete az állam és a magánbiztosítók együttműködése. Az állam ebben a kapcsolatban mint szabályozó, törvényhozó hatóság, mint a díjtámogatást nyújtó szereplő és mint végső viszontbiztosító szerepel. A magánbiztosítási szektornak a kapcsolatban mint a kockázatokat felmérő ügynöknek, kárrendezési szakértőnek és a szabályok betartását kikényszerítő szereplőnek van meghatározó szerepe.

\section{A magyarországi felelősségbiztosítási rendszer}

\section{A magyarországi környezeti felelősségbiztosítási rendszer jogi háttere}

A 2011. április 25-én elfogadott Alaptörvény az egész államszervezetre és a jogrendszerre nézve kötelező erővel szabályozza a természeti erőforrások védelmét - a jövő nemzedékeinek érdekében (a Hitvallás 8. felhívása, az Alapvetés P. cikk, a Közpénzek fejezet 38. cikk (1) 
bekezdése). Hagyományos alapjogi gondolkodást tükrözve: elismeri az egészséges környezethez való jogot (XX. cikk) (1) bekezdés: „Mindenkinek joga van a testi és lelki egészséghez." Mindenki számára, állampolgárságra tekintet nélkül, biztosítja az egészséges környezethez való jogot (XXI. Cikk) (1) bekezdés: „Magyarország elismeri és érvényesíti mindenki jogát az egészséges környezethez." A "szennyező fizet" elvet a jogalkotó alkotmányos szintre emeli. (XXI. cikk) (2) bekezdés: „Aki a környezetben kárt okoz, köteles azt - törvényben meghatározottak szerint - helyreállítani vagy a helyreállítás költségét viselni."

A kötelező felelősségbiztosítás tipikusan a szennyezések következményeinek a felszámolását szolgálja, és mint ilyen a múlt öröksége miatt biztosan nem oldható meg a költségvetés támogatása nélkül. (Kerekes, 1993)

Az EU 2004/35/EK Irányelve a környezeti károk megelőzése és felszámolása tekintetében - 2007. április 30-tól vált a magyar jog részévé, a Kvt. és más jogszabályok módosítása, illetve új jogszabályok megalkotása révén. A környezeti károk megelőzését és helyreállítását a „szennyező fizet” elvének előmozdításával kell végrehajtani a Szerződésben leírt módon, a fenntartható fejlődés elvével összhangban. Magyarországon a 219/2011. (X. 20.) Korm. rendelet szabályozza a veszélyes anyagokkal kapcsolatos súlyos balesetek elleni védekezéssel kapcsolatos előírásokat.

A gazdasági szereplők ösztönzése céljából, hogy olyan intézkedéseket fogadjanak el, és olyan eljárásokat dolgozzanak ki, amelyek minimálisra csökkentik a környezeti károk kockázatát, a kormányrendeletnek megfelelően az ott meghatározott alsó és felső küszöbértékű veszélyes anyagokkal foglalkozó üzem üzemeltetőjének az abban meghatározott tartalmi és formai követelményeknek megfelelő biztonsági elemzést kell készítenie, és az abban foglaltak szerint köteles működni.

Az irányelv alapelvének megfelelően az a gazdasági szereplő, akinek tevékenysége környezeti kárt, illetve az ilyen jellegű közvetlen kárveszélyt okozta, pénzügyi felelősséggel tartozik. Az 1995. évi LIII. törvény a környezet védelmének általános szabályairól egyértelműen fogalmaz a vezető tisztségviselők felelőségéről: A gazdasági társaság és egyéni cég azon tagjai (részvényesei), valamint vezető tisztségviselői, akik olyan határozatot (intézkedést) hoztak, amelyről tudták, vagy az elvárható gondosság mellett tudhatták volna, hogy annak végrehajtásával a társaság környezetkárosodást okoz, a társaság megszűnése esetén korlátlanul és egyetemlegesen felelnek a társaságot terhelő, a társaság által nem teljesített helyreállítási és kártérítési kötelezettségekért. Mentesül a felelősség alól a gazdasági társaság és egyéni cég azon tagja (részvényese), illetve vezető tisztségviselője, aki a határozat (intézkedés) meghozatalában nem vett részt, a határozat ellen szavazott, illetve az intézkedéssel szemben tiltakozott.

\section{A magyarországi felelősségbiztosítási piac fejlődése}

A magyar felelősségibiztosítási piac alulfejlett, GDP-arányosan sokkal kevesebbet költünk rá, mint a fejlett nyugati államok. (Pandurics - Markó, 2015) Az elmúlt öt esztendő statisztikája azt mutatja, hogy a válság után újra emelkedésnek indultak a díjbevételek, és ezen belül a felelősségbiztosítások növekedési üteme meghaladta a vagyonbiztosításokét. Ebben szerepet játszott a szabályozórendszer változása is. A felelősségbiztosítási szerződések száma a 2016. első negyedévi 105e db-ról 2019 első negyedévére közel 130e db-ra emelkedett, melyből 57 százalék volt általános felelősségbiztosítási szerződés, a többit szakmai felelősségbiztosítási szerződések terén kötötték (1.ábra). Az átlagdíjak enyhén növekedtek, míg az általános felelősségbiztosítások átlagdíja a 2016. évi 260eFt-ról közel 280eFt-ra, addig a szakmai felelősségbiztosítások átlagdíja 43,5eFt-ról 44,5eFt-ra emelkedett. Ennek megfelelően a díjelőírások is emelkedtek (2. ábra), ami inkább a darabszám-növekedésnek, mintsem az átlagdíj növekedésének köszönhető. A fejlettebb piacokhoz képest továbbra is alacsony átlagdíjak a nem megfelelő, kockázatarányos biztosítottságra utalnak. Ez azt takarja, hogy az okozható kárhoz képest jóval alacsonyabb összeget/kártérítési limitet választ az ügyfél.

1. ábra: A felelősségbiztosítások darabszámának az alakulása 2016-2019.

- Általános felelősségbiztosítás db - Szakmai felelősségbiztositás db

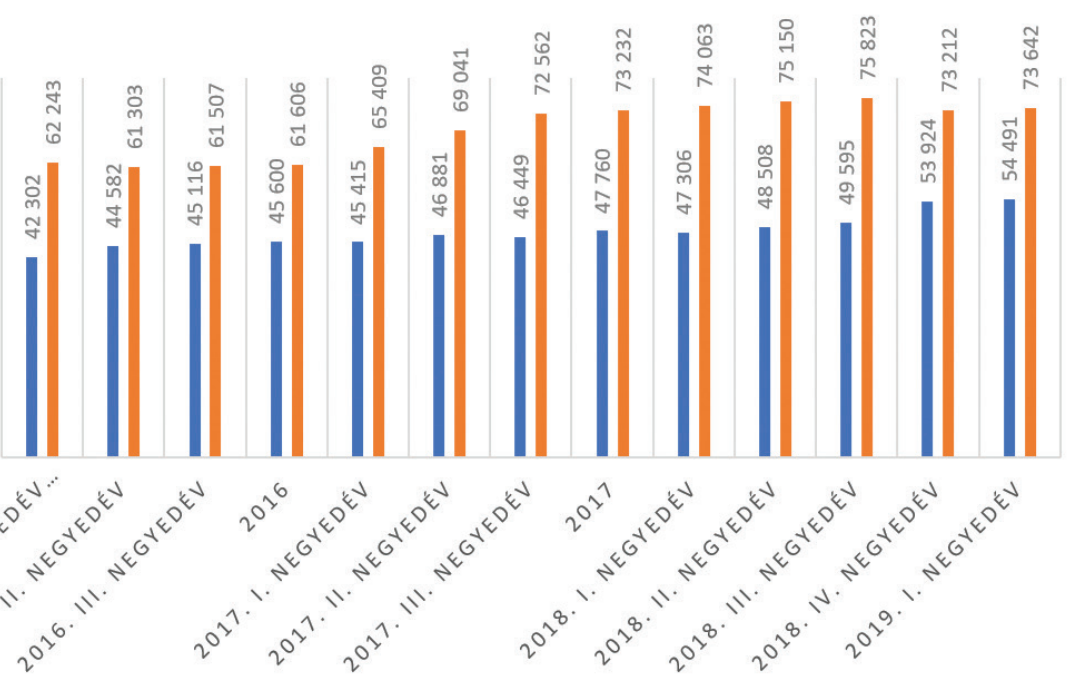

Forrás: $M N B$ 
2. ábra: A felelősségbiztosítások negyedévenkénti halmozott díjbevétele 2016-2019.

\section{- Általános felelösségbiztositás mHUF}
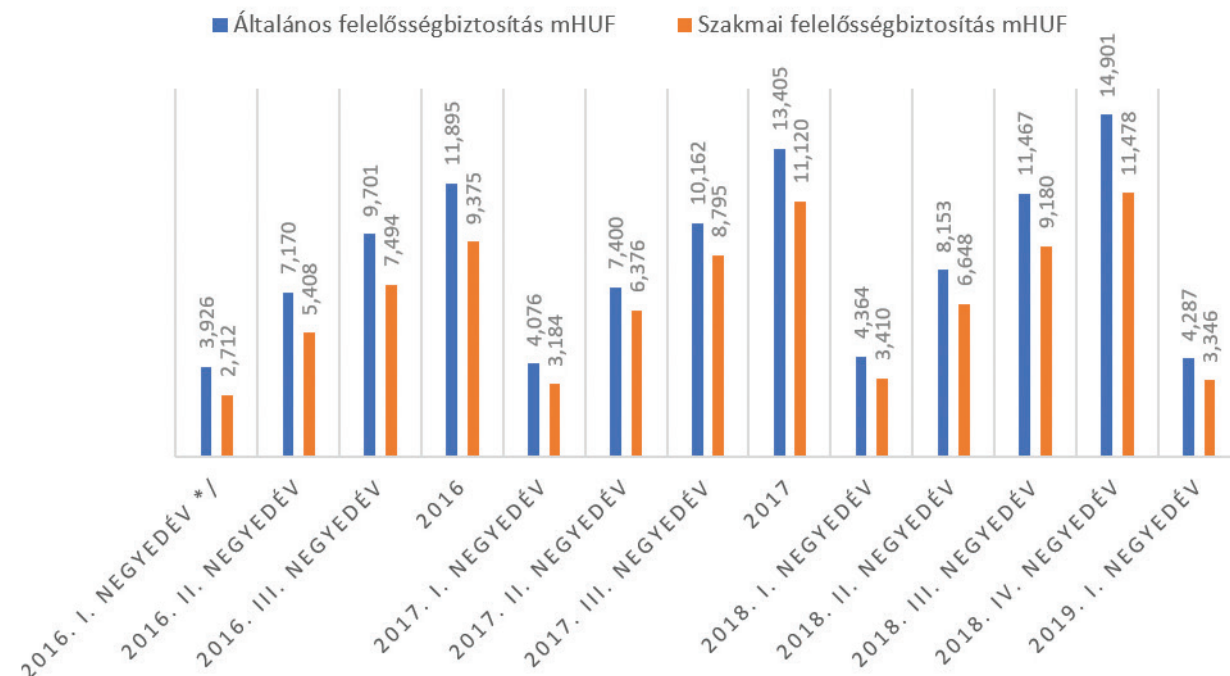

Forrás: $M N B$

A 2014-ben hatályba lépett új Polgári Törvénykönyv nagyban érintette a felelősségbiztosítási piacot is. Egyik oldalról megjelent a kártéritések esetében a sérelemdíj mint új kártéritési fogalom, illetve a vezető tisztségviselők felelősségének szabályai is konkrétabbá váltak az új jogszabályban. A piac további élénkülése részben annak a jogalkotói tevékenységnek volt a következménye, amely az építőipari tervezési és kivitelezői tevékenységet végző vállallkozások számára előírta a kötelező felelösségbiztosítást. A gazdasági növekedés várhatóan jó hatással lesz a piac alakulására is, nő a gazdaság szereplöinek a kitettsége, viszont többen engedhetik meg maguknak a növekvő kockázatok kezeléséhez szükséges ráfordítást.

A biztosítás elterjedése nemcsak attól függ, hogy milyen mértékben bővül a felelősségbiztositással lefedett kockázatok köre (pl. kiberbiztosítás stb.), hanem attól is, hogy a szolgáltatók, üzemben tartók milyen mértékben vannak tisztában az általuk viselt kockázattal, és milyen ösztönzők vannak annak elkerülésére. Még mindig jellemző, hogy a kár bekövetkeztekor az ügyfél csak azt tudja, hogy biztosítása van, de nem tudja, hogy milyen kockázatra és milyen biztosítási összeggel. Egy kár bekövetkezése során a média sokszor téves értelmezése is hatalmas reputációs kockázatot hordoz magában.

Nálunk az esetek többségében az egyes felelösségbiztosítások díját, a biztosítási összeget, területi hatályt, retrospektív kiterjesztés mértékét piac határozza meg, a felügyelő hatóság csak korlátozott esetekben fogalmaz meg forgalomhoz kötött elvárásokat.

Az általános felelösségbiztosítás körében inkább a felróhatóságalapú ösztönzőrendszer a jellemző, főleg egyes termék- és néhány szakmai felelősségbiztosításnál, valamint a veszélyes üzemi tevékenység esetén az objektív felelősség kategóriája az irányadó, azaz az üzemben tartó „szennyező” fizet elv az elfogadott. Csák Csilla „A «szennyező fizet» elv értelmezése és alkalmazása” című cikkében kifejti, hogy a szennyező fizet elve és a felelősség elve összetartozó, de nem teljes mértékben azonos tartalmú rendszert képez. (Csák, 2014)

Mivel az állam nem szabályozza a biztositási összegeket, ezért az esetek többségében ezeket nagyon alacsony limitekre kötik (ld. a MAL Zrt. vörösiszap-tároló esete), amelyek nem jelentik a problémák valós megoldását. (Nagy - Jámbor, 2014)

Több olyan kockázat van Magyarországon, ahol a biztosítottsági kötelezettséget és annak mértékét az állam előírja. Három olyan területet érdemes megvizsgálni, melyek tapasztalatai segíthetik a kötelező környezeti felelősségbiztosítás bevezetését.

A kötelező biztosítások gyakorlata Magyarországon

\section{Kötelező gépjármü-felelősségbiztosítás}

Kötelező gépjármű-felelősségbiztosításról szóló a 2009. évi LXII. törvény két olyan alap létrehozását írja elö, amely a „gazdátlan” károk fedezését szolgálja.

Kártalanítási Alap: A biztosítók által létrehozott és finanszírozott pénzalap, mely azon biztosítónál (a továbbiakban: felszámolás alatt álló biztosító) a károkozás időpontjában a biztosítási szerződés alapján fedezettel rendelkező üzemben tartó gépjárművével okozott károk megtérítését fedezi, mellyel szemben a biztosító tevékenységét engedélyező tagállamban felszámolási eljárás megindult;

Kártalanítási Számla (Garanciaalap): A biztosítók által létrehozott és folyamatosan finanszírozott pénzalap, amelynek feladata a biztosítási kötelezettség ellenére biztosítással nem rendelkező üzemben tartó gépjárműve által vagy az e törvényben meghatározott korlátozásokkal az ismeretlen üzemben tartó gépjárműve által, továbbá az ismeretlen gépjárművel okozott károk, valamint meghatározott egyéb károk megtérítése, amennyiben a kötelezettségvállalás országa Magyarország. A MABISZ elkülönített szervezeti egysége mint a Kártalanítási Számla és a Kártalanítási Alap kezelője számol el a biztosítókkal.

\section{Nukleáris létesítmények felelősségbiztosítása}

A nukleáris létesítmények felelősségi körét az „1996. évi CXVI. törvény az atomenergiáról” szabályozza. A Párizsi Egyezménnyel összhangban a nukleáris létesítmények üzemeltetője az abban meghatározott limittel köteles felelősségbiztosítást kötni, a limit fölötti károkat pedig az állam egy további mértékig megtéríti. A nemzetközi gyakorlat az, hogy a nukleáris létesítmények üzemeltetői egy poolba tömörülve, egy saját captive-ot alakítanak, vagy a biztosítók helyi poolokat alakítanak a helyi kapacitás létrehozására, amelyet tovább viszontbiztosítanak más nemzetközi pooloknál vagy egyedi viszontbiztosítóknál a kívánt limit elérése érdekében. 


\section{Mezőgazdasági biztosítások}

A mezőgazdasági termelők öngondoskodáson alapuló felelősségének megerősítése, az állami segítség hatékonyabbá tétele, valamint az érintettek arányos felelősségvállalása jellemzi a több pillérre épülő struktúrát. Az érvényben lévő komplex mezőgazdasági kockázatkezelési rendszert, a mezőgazdasági termelést érintő időjárási és más természeti kockázatok kezeléséről szóló 2011. évi CLXVIII. törvény (továbbiakban: Mkk tv.) foglalja egységes szerkezetbe. Ez az intézkedéscsomag új elemként bevezette a mezőgazdasági biztosításokra vonatkozó támogatási konstrukciót is. Jelenleg a magyar mezőgazdasági kockázatkezelési rendszer két pillérre épül:

I. pillér: a notifikált állami támogatást tartalmazó agrárkárenyhítési rendszerre, mely a növénytermesztés legfontosabb természeti és időjárási kockázatait kezeli. A rendszer lényege, hogy a tevékenység és a területi méret függvényében kötelező díjbefizetést ír elö, amit a gazdák befizetnek a Kárenyhítési Alapba, melyet a befizetéssel azonos összeggel az állam is megtámogat. A kifizethető kár maximális mértéke is meghatározott a kockázatok függvényében, de csak az Alap vagyonának a terhére. A II. pillér keretében meghatározott kockázatokra további biztosítások megkötésének ösztönzése végett, azok a gazdák, akik nem rendelkeznek a II. pillér keretében magánbiztosítással, csökkentett kárenyhítést kapnak az Alapból.

A II. pillér: a legfontosabb természeti és időjárási kockázatokra kötöttönkéntes mezőgazdasági biztosítás, melynek díjához azállam támogatást nyúit, a növénytermesztéssel foglalkozó termelők részére. Az intézkedés célja, hogy azon termelők, akik az I. pillér szerinti kárenyhítési alap nyúitotta védelemnél nagyobb mértékben kívánják kezelni az időjárási jelenségekből adódó termelési kockázataikat, a kockázatkezelési eszköztárukat a speciális mezőgazdasági biztosítással kiegészíthessék. Az intézkedés bevezetésével kibővül a biztosított káresemények palettája, és növekszik a biztosítással lefedett területek aránya is.

Ez a fajta támogatási konstrukció jól példázza, hogy a biztosítási kultúra állami támogatás nélkül alig lenne létrehozható. A biztosítási díjat mint kockázatkezelési költséget a termelők az állami támogatás nélkül nem tartják kigazdálkodhatónak. A kétpilléres rendszer ösztönzi őket a biztosítás megkötésére.

\section{Környezeti károk törvényi kezelése Magyarországon}

Már az 1995. évi LIII. törvény a környezet védelmének általános szabályairól kimondja, hogy a természeti örökség és a környezeti értékek a nemzeti vagyon részei, amelyeknek megőrzése és védelme, minőségének javítása alapfeltétel az élővilág, az ember egészsége, életminősége szempontjából. A törvény a környezet védelmének általános szabályairól a IX. fejezetében, a 101. paragrafus (4.) bekezdésében azt mondja, hogy: „A környezethasználó külön jogszabály szerint - tevékenységének megkezdéséhez kötelezhető környezetvédelmi biztosíték adására, céltartalék képzésére vagy felelősségbiztosítás megkötésére."

A 101. paragrafus 5. és 6. pontja rendelkezik a „környezetvédelmi biztosítékadás és a környezeti felelősségbiztosítás problémájáról. „(5) A környezethasználó külön kormányrendeletben meghatározott tevékenységéhez környezetvédelmi biztosíték adására köteles, továbbá a tevékenységével okozható, előre nem látható környezetkárosodások felszámolása finanszírozásának biztosítása érdekében - külön jogszabályban meghatározott feltételek esetén - környezetvédelmi biztosítás kötésére kötelezhető. A környezethasználó a külön kormányrendeletben meghatározottak szerint környezetvédelmi céltartalékot képezhet a jövőben valószínűleg vagy bizonyosan felmerülő környezetvédelmi kötelezettségeire."

(6) Az (5) bekezdésben meghatározott tevékenységeket, valamint a biztosíték formáját és mértékét, felhasználásának feltételeit, elszámolásának és nyilvántartásának szabályait, továbbá a környezetvédelmi biztosítás szabályait a Kormány rendeletben állapítja meg."

Vagyis lehetőséget ad a törvény egy ilyen kötelező felelösségbiztosítási rendszer felállítására és működtetésére. A törvény idézett részlete értelmezhető úgy, hogy az érintett környezethasználó ezzel az okozott kárért az esetleges megszűnését vagy fizetésképtelenségét követően, illetve az elévülési időn túl felmerült kártérítési igényekért is köteles helytállni, vagyis a felmerülő helyreállítási költséget, illetve kártérítést a biztosítótársaság, amellyel az adott károkozó szerződésben áll vagy állt, kell, hogy állja." (Kerekes, 1993)

\section{Lehetőséget ad a törvény egy kötelező felelősségbiztosítási} rendszer felállítására és müköodtetésére.

A jelenlegi hazai gyakorlat az, hogy az Általános vagy Tevékenységi Felelősségbiztosítási szerződésekből és a Szolgáltatói Felelősségbiztosítási feltételek során a környezetben okozott és a környezetet veszélyeztető tevékenységgel összefüggésbe (környezetszennyezés) hozható károkat is kizárják - bár, ha szükséges, külön kockázatként beemelhetők -, és önálló biztosítási fedezetek köthetők. Még ha a biztosítás kötését elő is írják, a központilag meghatározott limitek hiányában a szerződésekben megfogalmazott biztosítási összegek messze a kívánt szint alatt vannak, miközben a kockázatok fedezéséhez szükséges kapacitások a hazai, illetve a nemzetközi piacon elérhetőek.

A környezeti kockázatokkal kapcsolatos biztosítások elterjedése nemcsak a biztosítási szektornak adhatna további lendületet, de a környezeti felelősségi viszonyok tisztázása ösztönzőleg hathatna további tőkebefektetésekre. Ma nincs Magyarországon kötelező környezeti felelősségbiztosítási előírás, központilag végiggondolt ösztönzőrendszer sem működik, kivéve néhány tevékenységet, melyek megkezdéséhez szükséges bemutatni környezetvédelmi biztosítást, mint például a hulladékgazdálkodási tevékenység engedélyezése esetén (439/2012 Kormányrendelet). Az ösztönzőrendszert és az ehhez köthető pénzügyi biztosíték rendszerét kell úgy kialakítani, hogy az mind az üzemben tartót, mind a potenciális károsultat a megfelelő elővigyázatossági intézkedések meghozatalára sarkallja, elviselhető terhet, de a jogos igényekre fedezetet nyújtson,

amennyiben a károkozó jogi vagy természetes személy kiléte nem megállapítható vagy fizetésképtelen, a károsult kárigénye akkor is érvényesíthető legyen. 
Ez utóbbinak hasonlóképpen kellene müködnie, mint a kötelező gépjármü-felelősségbiztosítási rendszerbe bevezetett Kártalanítási Számla, illetve Kártalanítási Alap, azzal a különbséggel, hogy az alaphoz való hozzájárulás a veszélyes üzem üzemben tartójának a költsége, de indulásakor elengedhetetlen az állami szerepvállalás. A tudatosság szintjének a növekedése nemcsak a felelősségbiztosítási igénnyel szembeni növekedést hozza magával, hanem növeli a kárigényérvényesítési hajlandóságát. Elvárható egy olyan rendszer létrehozása, amely szélsőséges esetek előfordulása esetén is biztosítani tudja az üzletmenet folytonosságát, ugyanakkor a prevenciós, kármegelőzési költségek olyan terheket jelentsenek a társaságok számára, amelyek még kigazdálkodhatók. Elkerülendő, hogy látszatintézkedések eredményeképpen a biztosítási összegek köszönőviszonyban se legyenek a potenciális károk nagyságával, és így az esetleges károk bekövetkezése esetén korlátozott fedezetet biztosítsanak a károkozó és ezáltal a környezethasználók számára.

Javaslat a környezeti felelősségbiztosítás bevezetésére

\section{A javaslat elözményei}

Ezzel kapcsolatosan már a 90-es évek közepén készültek javaslatok, amelyek mind az állam szerepét, mind pedig a magánbiztosítók szerepvállalását taglalták. (Kerekes, 1993) Külön kezelték a kötelező rendszert, amely a "gazdátlan károkért” való helytállást biztosítaná. Ide tartoznának azok a károk, ahol:

- $\quad$ a kár okozója nem ismert (jogutód nélkül megszűnt stb.),

- a kár okozója ismert, de fizetésképtelen,

- az elévülési időt túllépi,

- költségeit a veszélyközösség állná.

A korábban említett nemzetközi gyakorlatok a magyarországi bevezetésre kevésbé alkalmasak, egyrészt a múlt környezeti kárainak öröklése következtében, másrészt pedig amiatt, hogy a környezettudatosság, a tudatos környezetvédelmi kultúra nem szerves része a vállalkozások mindennapi tevékenységének. Egy kötelező környezeti felelősségbiztosításnak mint a környezetvédelem egyik eszközének a bevezetése és az állami szerepvállalás terheinek a csökkentése számos kérdés tisztázását igényli.

Cél egy olyan rendszer létrehozása, amely a vállalkozások számára még elviselhető, hosszabb távon csökkenő költségek mellett javuló környezetminőséget eredményez.

Mi történik azokkal a károkkal, amelyek a múltban keletkeztek, az új tulajdonosok nem tudnak vagy nem akarnak felelősséget vállalni értük, illetve a múltra vonatkoznak, de hatásuk még nem vagy csak korlátozottan ismert. Ennek terhei a múltbeli privatizációs szerződések többségében azok környezeti károsodásra vonatkozó kitételeinek megfelelően az államra hárultak. Hasonló problémák a jövőbeni tulajdonosváltozásoknál is felléphetnek, amennyiben a régi vagy az új tulajdonos a múltban keletkezett környezeti károkozásból fakadó terheket nem tudja vagy nem akarja teljesíteni. A már ismert károk nem tartoznak a biztosítási események kategóriájába. Ezek következményeinek a felszámolása, a környezet helyreállításának a költségei továbbra is az állami költségvetést fogják terhelni.

Cél egy olyan rendszer létrehozása, amely a vállalkozások számára még elviselhető, hosszabb távon csökkenő költségek mellett javuló környezetminőséget eredményez. Különbséget kell tenni a társadalom és az egyének kockázata között, az utóbbi csak néhány embert érinthet, míg a társadalmi károk az egész gazdaságot. (Kerekes, 1993) A gazdaságpolitika egyik feladata ezen társadalmi kockázatok mérséklése. A piaci szereplők bevonásától a hatékonyság javulása várható, jól behatárolható károsultra koncentrálva, de az ezzel együtt járó társadalmi kockázatok kezelése miatt az állam szerepvállalása elengedhetetlen.

\section{A magánbiztosítók várható szerepe}

A múltban keletkezett, de még nem ismert károkra a biztosítók valószínűleg maximum ötéves időtartamot felölelő, retrospektív fedezetet nyújtanak, és bár ez a retrospektív vállalási hajlandóság a felelősségbiztosítások terén ismert, de vállalása és az árazásuk kérdéses. Az ilyen biztosítások léte elsősorban a viszontbiztosítási piac vállalási hajlandóságától függ.

A jövőben keletkezett környezeti károk fedezetére elképzelhető egy kötelező felelösségbiztosítási rendszer létrehozása, de ez átmeneti időszakot igényel, amelyben az állami szerepvállalás mértéke nem lehet elhanyagolható. Ennek kialakításához fel lehet használni a kötelező gépjármüfelelősségbiztosítás, illetve a mezőgazdasági biztosítások terén meglévő állami szerepvállalás tapasztalatait.

A mindenkori tevékenység környezetkárosító kockázatának és üzleti volumenének a függvényében kell kialakítani egy olyan minimálisan elvárható biztosítási összegre vonatkozó kötelezettséget, amely a várható károk elhárítására, a környezeti infrastruktúra lehetséges visszaállítására átlagos fedezetet nyújt. Az így kialakított rendszer egyszerű, kockázati besorolása a meghatározott tevékenységi engedélytől függ, a díj és a fedezet mértéke egy táblázatban összefoglalható, nem kíván extra értékesítési kapacitást. A vezetés mindenkori kockázatvállalásának mértékétől, illetve a hatóság egyedi elöírásai alapján további kiegészítő biztosítások legyenek köthetők. A kötelező felelősségbiztosítás bevezetésétől elvárható, hogy ne fordulhasson elő olyan eset, hogy a megkötött felelösségbiztosítás limitje messze alatta legyen a lehetséges károkozás mértékének. Jó példa erre a MAL Zrt. vörösiszapkára, ahol a megkötött fedezet a $10 \mathrm{mFt}$-ot sem haladta meg, miközben a magyar kormánynak összesen 38 milliárd forintjába került a vörösiszap-katasztrófát követő károk helyreállítása. Ebből 21 milliárd forintot a környezeti elemek helyreállítása emésztett fel.

Mivel lesznek olyan vállalkozások, amelyek nem képesek, vagy nem akarnak a vagyonukat is meghaladó károkra biztosítást kötni, az esetleges káresemény bekövetkezésekor csődvédelmet kérnek, vagy felszámolási eljárás alá kerülnek. Az államnak az így keletkezett „gazdátlan károkra” is fedezetet kell biztosítania. A gazdátlan károk terheit nem lehet azonnal a biztosítási piacra 
zúdítani, szükséges egy átmeneti időszakot biztosítani, ameddig a biztosítók az ezirányú kártalanítási/kárenyhítési alapot fel tudják tölteni. Ehhez hasonló konstrukciók mind a kötelező gépjármű-felelősségbiztosítási rendszerben, mind pedig a mezőgazdasági károk terén léteznek. Az alap feltöltésének a terheit a kötelező rendszer bevezetése során az így kialakított veszélyközösségnek kell viselnie. Míg a mezőgazdasági biztosítások terén a károsult személye jól megfogható, addig a környezeti károk sok esetben egy szélesebb társadalmi csoportot is érinthetnek. A környezeti károkozás nagysága, a mezőgazdasági biztosítások éves fordulójával szemben, évekkel az esemény után is kiderülhet. Példaként említhetjük a Metallochemia vagy a Vegyiművek garéi hulladéklerakójának az esetét, és a példákat még hosszan sorolhatnánk.

A biztosítási kockázat árazása a megfelelő hazai kárstatisztikák hiányában nehézkes. Elsősorban a viszontbiztosítók nemzetközi tapasztalataira építve lehet elindulni, amit korrigálnak az adott ország környezeti károkozási tapasztalatai és azok vélt vagy valós kockázata. Ezen a téren a hazai biztosítók kockázatvállalási hajlandósága korlátozott - csak néhányan vállalnak környezeti felelősség kockázatot, és azt is nagyon alacsony biztosítási összeggel.

A kötelező környezeti felelősségbiztosítási rendszer kialakításához és az elengedhetetlen állami szerepvállaláshoz az alábbi két javaslatot tesszük.

\section{A közvetlen díjtámogatás szerepe}

Egyik alternatívaként célszerű volna a biztosítók kockázatvállalását egyátmeneti időszakban bátorítani, akár egy díjtámogatási vagy például a vállalkozásoknál egy adótámogatási konstrukció bevezetésével, hogy ezeket a költségeket a bevezetési időszakban elviselhetővé és tervezhetővé tegyük a vállalkozások számára. A rendszer hosszabb távú stabil működése lehetőséget adna a direkt biztosítóknak egy olyan kárstatisztika kialakítására, amely alapot nyújthat a szükséges aktuáriusi számításokhoz, ami támogathatja a viszontbiztosítókkal való megállapodásokat A támogatás mértékét befolyásolhatja, hogy az állam - mint felügyelö hatóság - a szabályozási oldalról milyen ösztönzőrendszer kialakítását támogatja, amely a mindenkori tevékenység veszélyességi és környezet-igénybevételi mértékétől függően előírja a szükséges pénzügyi biztosíték kötelezettségének mértékét.

\section{A kétpilléres környezeti felelösségbiztosítási rendszer kialakítása}

A másik általunk javasolt megoldás a mezőgazdasági biztosítások támogatási rendszeréhez hasonlóan egy kétpilléres rendszer bevezetése eltérő állami támogatási konstrukcióval.

Míg a mezőgazdasági biztosítások esetén már működő kétpilléres rendszerben a gazdák a „saját káraik” fedezésére több ösztönzőt is látnak (saját károm fedezésére magasabb összeg az I. pillérből, díjtámogatás), addig a környezeti felelősségbiztosítások a harmadik félnek okozott károk következtében fellépő társadalmi feszültségek csökkentését szolgálják.
A rendszer fenntartásához elengedhetetlen az állam mint szabályozó hatóság kötelező környezetvédelmi biztosítás kötésére vonatkozó elöírása és a kezdeti fázisban közvetlen támogatása.

Pillér I

A cél az, hogy a kötelező környezeti felelősségbiztosítás során létrejövő veszélyközösség kockázatát egy poolban egyesítsük. Azt gondoljuk, hogy a kötelező jelleg következtében az állam által kikényszerített pool bevételének nemcsak a normál működésből fakadó kockázat mértékétől és forgalomtól függő „sztenderd” károkra kellene fedezetet nyújtania, hanem a jövőbeni gazdátlan károkat is ebből kellene fedezni. Tehát a díj egy része - a kötelező gépjármű-felelősségbiztosítás terén szerzett tapasztalatokhoz hasonlóan - egy Kártalanítási Alapba kerülne, amely az ismeretlen vagy fizetésképtelen károkozó által okozott károkra nyújtana fedezetet. Ameddig nem alakul ki a helyes árazást támogató kárstatisztika, a pool veszteségét átmenetileg a költségvetésnek kellene kipótolnia. Működése olyan, mint a környezeti felelőségbiztosítási károkra szakosodott állami irányítású „,captive”, amely az így kialakított veszélyközösség belső igényeit elégíti ki, és a kvázi normál káreseményeken túli katasztrófakárokra egy nem arányos katasztrófafedezetet is köthet a viszontbiztosítási piacon. Ezzel csökkenteni lehetne a költségvetésnek a károkozás során fellépő közvetlen terheit, hiszen egy esetleges veszteséget kellene addig fedeznie, amíg létrejönne egy tevékenységtől és méretnagyságtól függő, kötelező biztosítási díjfizetési rendszer.

A kockázatelbírálók feladata, hogy felmérjék az egyes társaságok kármegelőzési intézkedéseit, és ennek megfelelően finomítsák a tevékenységi engedély megadásához kötött kockázati besorolásukat. Ezen keresztül is ösztönözni lehetne a szükséges kármegelőzési intézkedések meghozatalát. Az évenkénti felülvizsgálat során dönthetnének a besorolás jövőbeni fenntartásáról, illetve más kockázati osztályba történő átsorolásáról. Ez a vállalatok részéről sokkal környezettudatosabb gondolkodáshoz vezetne, hiszen a megfelelő intézkedések meghozatala esetén költségeit csökkenthetné.

A rendszer stabilizációja után célszerü önálló kockázati közösségként egyben fenntartani, esetlegesen a piaci szereplőknek mint jövőbeni működtetőknek felajánlani.

\section{Pillér II}

A Pillér I. keretén belül kialakított rendszer csak az elöre kialakított sztenderd limitek mértékéig nyújt fedezetet, így nem tudja pontosan követni az egyes tevékenységek pontos kockázatát.

Minden vállalkozás maga döntheti el a saját kockázatvállalási hajlandóságánakés kármegelőzési intézkedéseinek megfelelően, hogy az adott limit fölött szándékozik-e a piacon további biztosítási fedezetet vásárolni. Mivel a környezeti károk bejelentése és azok mértékének meghatározása sok esetben csak évek múltával lehetséges, a felelősségbiztosítások kockázatainak árazása megfelelő kárstatisztikák hiányában nehezen meghatározható, így a biztosítótársaságok a bevezetés 
időszakában fokozott kockázatot vállalnak. Ennek megfelelően megfontolandó egy átmeneti időszakra a közvetlen állami dítámogatás bevezetése, ami bátorítaná a vállalkozásokat további egyéni, magasabb kockázatú fedezetek vásárlására, ugyanakkor a kockázatoknak megfelelő díjszint emelné a biztosítók kockázatvállalási hajlandóságát.

Az általunk javasolt megoldás fokozatosan csökkentené a környezeti károk terén az állam terheit, javítaná a környezettudatosságot a vállalkozások körében, miközben a piaci biztosítóknak nagyobb teret nyújthat az alapszolgáltatás feletti kockázatok terén.

\section{Az állam szerepe a kétpilléres rendszerben}

Azállam mint felügyelő hatóság a korábban említetteknek megfelelöen dönti el, hogy melyek azok a területek, ahol kötelezően elöírja a felelősségbiztosítás meglétét, azaz mely tevékenységeket kívánja a poolba bevonni, továbbá a tevékenység veszélyességi besorolásától függően előírja biztosítási összeg, esetleges önrész kialakítását. Mivel az első Pillér keretén belül létrehozott pool veszteségét is az induló időszakban neki kell fedeznie, ezért a sztenderd díjstruktúrát is neki kell jóváhagynia. A biztosítás díja a mindenkori tevékenység veszélyességi, kockázati besorolásától, az üzletmenet nagyságától és az elvárt fedezet mértékétől függhet. A megfelelő kockázatelbíráló kapacitást akár a poolra épülő állami környezeti felelősségbiztosítási captive is kiépítheti, de az egész működtetése idővel a piacra is bízható. A II. pillérben való szerepvállalása mindenképp csak átmeneti, a nagyobb kockázatok piaci bevezetését szolgálná

Azállam a felelősségbiztositási kötelezettségen túl az egyes vállalkozások számára a fokozottabban veszélyes tevékenységi engedélyek megadásakor magas önrész esetén céltartalékképzést is elöírhat.

\section{Következtetések}

A környezet tisztasága megőrzésének társadalmi hasznossága messze meghaladja a rövid távú piaci, gazdasági érdekeket, az állami szerepvállalás a környezettudatosság kialakításában elengedhetetlen. A magyar piacon a nemzetközi piachoz hasonlóan hozzáférhetők azok a pénzügyi megoldások, amelyek elengedhetetlenek ahhoz, hogy a kockázataikat jól ismerő vállalkozások vezetői megfelelő kockázatmenedzsmenttel irányítsák tevékenységüket.

Az általunk javasolt kétpilléres megoldás a környezet védelmét és a harmadik félnek okozott károk fedezését a magánbiztosító szerepének fokozatos növelésével szeretnélétrehozni. Ugyanakkor a biztosítótársaságok óvatossága, korlátozott kockázatvállalása a hosszú távú bizonytalanság miatt érthető, a piaci biztosítás költségei elvárható reális fedezetek mellett egyik napról a másikra nem terhelhetők rá a vállalkozásokra. Az állam egy kötelező rendszer bevezetésével segíthet egy olyan veszélyközösség - „környezetfelelösségi captive” -kialakításában, amely egyátmeneti időszak után biztonságosabb müködést eredményezne, és hosszabb távon az élhetőbb környezet kialakításához járulna hozzá

\section{IRODALOMJEGYZÉK}

Fuglinszky, Ádám (2010): Kártéritési jog, Budapest CompLex

78-84. . Barnes, P. H. (2002): Approaches to community safety: Risk perception and social meaning. Australian Journal of Emergency

Cruz, A. M. - Steinberg, L. J. - Vetere Arellano, A. L. - Nordvik, J.-P. - Pisano, F. (2004): State of the art in Natech risk management. Crík Cillt (2014): A

" Csapó, O (2015): A tërnyezti felelöség határai. PhD értekezés. Pármány Péter Katolikus Egyetem https:/liak ppke hu/uploads/ articles/12332/file/CSapo_dolgozat_vegleges(1).pdf Letöltve 2019.07.20.
Faure, M. G. (2006): EconomicCriteria for Compulsory Insurance The Geneva Papers on Risk and Insurance - Issues and Practice,

31(1), pp. 149-168. https://doi.org/10.1057/palgrave.gpp.2510063

DIRECTVE 2004/35/CE OF THE EUROPEAN PARLIAMENT AND OF THE COUNCIL of 21 April 2004 on environmental liability with regard to the prevention and remedying of environmental damage. (Environmental Liability Directive, 2004)
Kerekes, S. (1993, nov): Gazdasági eszközök akalmazása a környezetvédelemben Javaslat ärnyezeti felelösségbiztositás létrehozására. Napi Gazdaság p. 15

Kerekes, S. - Kovács, E. - Kék M.: (1997. augusztus) A kötelezö környezeti felelösségbiztositás mint helytállást biztositó lehetöség a polgárjogi úton nem érvényesithető kártéritési igények esetén. Környezetvédelmi és Területfejlesztési Minisztérium Közgazdasági Martin-Ortega, J. - Brouwer, R. - Aiking, H. (2011): Application of a value-based equivalency method to assess environmental damage
compensation under the European Environmental Liability Directive. Journal of environmental management, 92(6), pp. 1461-1470. https:///doi.org/10.1016/j.j.jenvman.2010.12.001 Monti, A. (2002): Environmental risks and insula

Environment-Related Risks.

Nagy, G. - Jámbor, V. E. (2014): A környezeti igazságosság vizsgálata a vörösiszap-katasztrớfa példáján. priorities of the world science: experiments and scientific debate. North Charleston, SC, USA: CreateSpace, pp. 95-100. Szalai, Â. (2015): Veszélyes üzemi felelősség - joggazdaságtani hatások. Állam- és Jogtudomány, 56(4), pp. 45-69. Szalai, Á. (2017): A másért viselt feeleösség és a helytállás joggazdaságtani elemzése. Âllam- és Jogtudomány, 58(1), pp. 71-94. Mandatory Climate Change Catastrophe Insurance. Pace Environmental Law Review, 27 . 691.

Trotter, R. C. - Day S. G. - Love, A. E. (1989): Bhopal, India and union carbide: The second tragedy. Journal of Business Ethics, 8(6), pp. $439-454$. 